Mario Vargas Llosa 
THIS PAGE INTENTIONALLY LEFT BLANK 
«BY RAYMOND LESLIE WILLIAMS "

\section{Mario Vargas Llosa}

A LIFE OF WRITING

University of Texas Press 
Copyright (C) 2014 by the University of Texas Press

All rights reserved

Printed in the United States of America

First edition, 2014

Requests for permission to reproduce material from this work should be sent to:

Permissions

University of Texas Press

P.O. Box 7819

Austin, TX 78713-7819

http://utpress.utexas.edu/index.php/rp-form

(2) The paper used in this book meets the minimum requirements of ANSI/NISO Z39.48-1992 (R1997) (Permanence of Paper).

LIBRARY OF CONGRESS CATALOGING-IN-PUBLICATION DATA

Williams, Raymond L.

Mario Vargas Llosa : a life of writing / by Raymond Leslie Williams. — First edition.

pages $\mathrm{cm}$

Includes bibliographical references and index.

ISBN 978-0-292-75812-4 (cloth : alk. paper)

1. Vargas Llosa, Mario, 1936-Criticism and interpretation. I. Title.

PQ8498.32.A65Z943 2014

$863^{\prime} .64-\mathrm{dc} 23$

2013048676

doi:10.756o/758124 